\title{
MAHDOLLISUUKSIEN HORISONTIT - DAVID GRAEBERIN HAASTATTELU
}

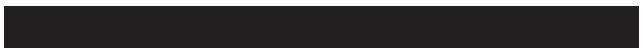

David Graeber (synt. 1961) on yhdysvaltalainen antropologi ja tunnettu anarkisti. Graeber loi akateemista uraa 1990-luvulta alkaen Yalen yliopistossa, kunnes yhtäkkiä vuonna 2007 hänen sopimustaan ei enää jatkettu. Aktivisti savustettiin ulos. Sittemmin Graeber on löytänyt työpaikkansa Lontoosta: vuodesta 2008 eteenpäin Goldsmithistä,ja viime vuodesta alkaen hän on toiminut antropologian professorina London School of Economicsissa. Omien sanojensa mukaan poliittinen toiminta on vienyt häneltä mahdollisuuden palata töihin yhdysvaltalaisiin yliopistoihin. Syksyllä 2011 Graeberin oli tarkoitus vain vierailla pikaisesti New Yorkissa. Hän kuitenkin tempautui lähes vuodeksi organisoimaan sittemmin Occupy Wall Streetina tunnettua liikettä.

Suurelle yleisölle Graeber tuli tunnetuksi vuonna 2011 julkaistusta kirjastaan Debt: The First 5000 Years. Kirja käsittelee velan yhteiskunnallista merkitystä ihmiskunnan vuosituhantisessa historiassa. Taloushistoriaa ja antropologiaa yhdistelevä laaja tutkimus resonoi tuoreeltaan onnistuneesti Occupy-liikkeen kanssa. Tulihan velan ja finanssijärjestelmään perustuvan luokkavallan vastustamisesta liikkeen keskeisiä kärkiä. Vuosi liikkeen hiipumisen jälkeen Graeber kokosi Occupy-kokemuksensa kirjaan The Democracy Project. Kirjassaan hän myös pyrkii määrittelemään modernin demokratian historian uudelleen.

Antropologin tammikuisen Suomen vierailun päätteeksi istuimme töölöläiseen ravintolaan keskustelemaan tutkimuksesta, luokasta, kapitalismin synnystä, demokratiasta ja tietenkin vallankumouksesta.

\section{YLIOPISTOT JA HALLINNOIVA LUOKKA}

Luennoit juuri Helsingin yliopistolla otsikolla "Antropologia ja hallinnoivan luokan nousu". Käsittelit luennossasi muutosta länsimaisten yliopistojen ybteiskunnallisessa roolissa. Väitteesi oli, että niistä on tullut pääasiassa finanssikapitalismille leimallisen hallinnoivan luokan tuottajia.

Juuri näin. Tietysti yliopistojen tehtävänä on aina ollut tuottaa hallinnoivaa luokkaa. Valistuksen ajalle oli leimallista, että uusia ajatuksia luoneet tieteilijät olivat pakotettuja toimimaan yliopistojen ulkopuolella. 1800-luvulta lähtien yliopistot alkoivat valmistaa virkamiehiä keskitetyn valtionhallinon palvelukseen. Sen rinnalla oli vivahdus tieteen autonomiaakin. Finanssikapitalismin aikakaudella yliopistot näyttäisivät pelkistyvän hallinnoivan luokan tuottajiksi. Tämä luokka asettuu järjestelmän uusintamisen palvelukseen ja työn muotoihin, jotka ovat myös yhteiskunnallisen hyvinvoinnin näkökulmasta kyseenalaisia, oli sitten kyseessä finanssijohdannaisten myynti, itseään ruokkivan byrokratian pyörittäminen, työläisten työn organisointi tai vastuun kantaminen edustuksellisen politiikan parissa.

Liitit myös väkivallan yliopistojen nykytilaan. Mistä tässä oli kyse?

Halusin puhua yliopistoista osana laajempaa yhteiskunnallista kehitystä. Yliopistot 
on yleensä mielletty paikoiksi joissa väkivalta ei voi olla läsnä. Jos nykyisin opiskelijat tai opettajat kyseenalaistavat finanssikapitalismin logiikan tai edustuksellisen päätöksentekojärjestelmän tuottamat päätökset, väkivallasta voi tulla arkipäivää myös yliopistoilla. Tästä on nähty esimerkkejä Kreikasta Yhdysvaltoihin.

Toisaalta halusin hieman kärjistää asioita yliopistoväelle. Olen nimittäin pudonnut ajat sitten laskuista, kuinka monesti olen kuullut helpot akateemiset viittaukset foucault'laiseen valta-analyysiin ja panoptikon-vertaukseen. Tiedäthän, nykyisin tottelemiseen ei enää tarvita suoraa väkivaltaa, koska ihmiset kontrolloivat itse itseään ja niin edelleen. Muistutin vain: "hei kaverit, panoptikon oli vankila!" Siis instituution osa, joka perustui puhtaasti väkivaltaan.

Panoptikonin tarinakin on puhdasta väkivaltaa. Idea ei ollut Jeremy Benthamin vaan hänen veljensä, joka sovelsi sitä käytäntöön lontoolaisilla telakoilla 1700-luvun lopussa. Koska työläiset olivat perinteisesti saaneet vain osan toimeentulosta rahapalkkana ja koska palkanmaksuväli saattoi venyä kuukausien mittaiseksi, olivat he ottaneet osan toimeentulon pitimistään puutavarana telakoilta. Kun vuosisadan lopussa Britannian finanssijärjestelmä vakiintui ja palkat alettiin maksaa rahana, yrittivät työläiset edelleen pitää kiinni oikeudestaan puutavaraan. Tämä ei työnantajapuolelle sopinut ja panoptikon tähystystorneineen pystytettiin telakalle, jotta puutavaraa kähveltäneet työläiset saatiin kiinni ja voitiin rangaistukseksi hakata. ${ }^{1}$

\section{LUOKKA, UUSI TYÖ JA VASEMMISTO}

Määrittelit keskiluokan luennollasi seuraavasti: "Kun näet kadulla poliisin, ja tunnet olosi turvallisemmaksi, olet keskiluokkaa." Halusit kaiketi tuoda esiin luokka-käsitteen poliittisuuden. Myös Suomessa luokka on palannut biljalleen takaisin paitsi akateemiseen tutkimukseen myös valtavirtaiseen poliittiseen kielenkäyttöön. Oc- cupy-liikkeen ansio lienee luokan palauttaminen yhdysvaltalaiseen keskusteluun?

Ehdottomasti, me toimme luokan takaisin. Se oli liikkeen yksi tärkeimmistä saavutuksista. Eikä kyse ollut vain luokasta, sillä yhtäkkiä amerikkalaiseen poliittiseen diskurssiin sisältyi ajatus luokkavallasta, yhdestä prosentista yhdeksääkymmentäyhdeksää vastaan. Tähän ei ollut kukaan kyennyt sitten 1930-luvun, vaikka aikaisempienkin yhteiskunnallisten liikkeiden yritys oli usein ollut kova.

On olemassa jo vuosikymmenten perinne väitteille, joiden mukaan vastakkainasettelujen aika on obi. Olemme kuitenkin näbneet, että luokkaperustainen massaliikebdintä on myös tulevaisuutta. Millaisena tällainen liike voisi mielestäsi ilmetä?

Tämä jäänee nähtäväksi. Juuri tätä kysymystä ihmiset käyvät parhaillaan läpi, niin teoreettisesti kuin käytännön vastarinnassakin. Globaaliksi äitynyt Occupy osoitti, että massaliikkeille on mahdollisuuksia ja tilaa. Se, että monet amerikkalaiset eivät enää katso kuuluvansa keskiluokkaan, on dramaattinen muutos. Yhdysvaltojenhan piti olla maa, jossa kaikki voivat tuntea kuuluvansa keskiluokkaan, ellei sitten ole Rockefeller tai koditon.

Toistaiseksi keskiluokan poliittisen tietoisuuden on kaapannut oikeisto, ei vasemmisto. Oikeisto on tiennyt aina, että luokka on hyvin tärkeä. Vasemmisto sen sijaan on pelännyt puhua koko asiasta. Tähän vaikuttaa varmasti kuviteltu historiallinen painolasti, mutta myös se, että valtavirtaisesta vasemmistosta on tullut osa hallinnoivaa luokkaa. Tämä on ilmiselvää ainakin Yhdysvaltain demokraattien osalta. Epäilemättä suunta on ollut pitkään sama myös Euroopassa. Kyse on eräänlaisesta "kunnioitetun" ja "vastuuta kantavan" vasemmiston itseymmärryksestä. Juuri tämä porukka pitää itseään edelleen keskiluokkana, kun enemmistö ihmisistä pitää itseään jonain aivan muuna. Valitettavasti vain oikeisto on kyennyt niittä- 
mään tämän siirtymän kurottamalla työväenluokkaisiin tuntoihin. Koskaan historiassa hallinnoiva luokka ja työväenluokka eivät ole pitäneet toisistaan. Kenelle on siis yllätys, ettei vasemmistosta välitetä nykyisinkään?

\section{Luokkapolitiikka ei kuitenkaan voi rakentua to-} tunnaisille kaavoille, kuten teollisen proletariaatin organisoitumiselle. Esimerkiksi Suomessa on viime vuosina pubuttu jonkin verran työn feminisoitumisesta, millä on tarkoitettu ybtäältä sitä, että juuri naisvaltaisiksi mielletyt alat ovat tulleet keskeisiksi kapitalistisessa arvon muodostuksessa, toisaalta sitä, että työ yleensä saa muotoja joibin naiset ovat aina joutuneet sopeutumaan, kuten jatkuva epävarmuus ja esimerkiksi koko persoonallisuuden valjastaminen työtehtävien suorittamiseen. Työväenluokka tietysti muovautuu myös työn muutoksen mukana. Voisit ehkä vielä avata lisää käsitystäsi luokasta.

Juuri mainitsemasi työn feminisoituminen on merkittävä muutos. Erityisen kiinnostavaa Occupyssa oli se, että uusi työ näkyi liikkeen perustassa. Ihmiset julkaisivat We are the 99\% -nettisivustolla lukemattomia kuvia itsestään pitämässä kylttejä, joihin oli kirjattu paitsi näkemyksiä yhdysvaltalaisen yhteiskunnan surkeasta tilasta myös kuvauksia henkilökohtaisen elämän koettelemuksista. Jälkeenpäin arvioin, että 85 prosenttia näistä oli naisia. Lähes kaikki sivuston ihmiset, miehet mukaan luettuna, työskentelivät jollakin niin sanotusti yhteiskunnallisesti hyödyllisellä alalla, kuten hoivatyössä, kasvatuksessa tai sosiaalityössä. He vaativat mahdollisuutta tehdä hyödyllistä työtä. Ongelma kuitenkin on, että jos haluaa tehdä tällaista työtä, siitä maksetaan niin vähän, että perheen elättäminen on mahdotonta. Siksi moni tuntee työnsä täysin hyödyttömäksi paskaduuniksi.

Tällaisen tyytymättömyyden tulisi määritellä perustavasti uudelleen käsityksemme työstä. Tässä olisi myös vasemmiston mahdollisuus, mikäli se kykenisi päivittämään käsityksensä työstä. Vaikeutena on edelleen irrottautua tehdasmaisen työn ja työläisyyden ajatuksesta. Siksi niin sanottu uusintava työ katsotaan edelleen toissijaiseksi. Jos vasemmistolla olisi kykyä ajatella tätä ihmisen syvintä tarvetta tehdä jotain mielekästä maailmassa ja jos se samalla kykenisi yhdistämään tilanteen luokkadiskurssiin, voisi vasemmistolla olla mahdollisuuksia. Tästä ollaan kuitenkin kaukana. Toisaalta olen optimistinen, sillä sellaisilla yhteiskunnallisilla liikkeillä,jotka kykenevät muistuttamaan siitä, mikä elämässä itse asiassa on tärkeää, on usein pitkän aikavälin vaikutuksia.

Jäin kaipaamaan kirjoissasi Debt ja The Democracy Project enemmän käsiteltävien ilmiöiden, siis velan ja demokratian, subdetta työhön. Viime aikoina oletkin kirjoittanut juuri työstä ja kutsunut useita nykytöitä, jotka eivät näyttäisi tuottavan minkäänlaista ybteiskunnallista byötyä, paskaduuneiksi (bullshit jobs) ${ }^{2}$. Vaikka työn tuottavuus on kasvanut merkittävästi ja teknologia mahdollistaisi paljon enemmän vapauksia ihmisille, työaika on käytännössä pidentynyt ja työehdot heikentyneet. Kuvaat termillä myös valtavaa joukkoa täysin turbia työmuotoja, kuten loputonta byrokratiaa, joilla juuri hallinnoiva luokka työllistää itsensä. Samalla kuvasit juuri turhautumista, joka nousee siitä, ettei nykytalous anna byödylliselle työlle arvostusta. Näetkö, että turbautuminen ja kokemus paskaduuneista voisi johtaa laajempaan työn vastaiseen liikkeeseen?

Ehdottomasti. Siitähän esimerkiksi perustulovaatimuksessa on perustaltaan kysymys. Tarkoituksena on varastaa työn arvostus palkkatyöjärjestelmältä yhteiskunnallisesti hyödylliselle työlle. Useimmat eivät edes tiedä, että perustulon ajatus tulee feministisestä perinteestä ja alun perin provokatiivisesta vaatimuksesta palkasta kotityölle. Vaatimuksen tarkoituksena oli osoittaa, että koko palkkatyöjärjestelmä on vääristynyt ja purettava. Kyse oli tietenkin myös siitä, että jos uusintavan työn merkitys tunnustettaisiin, päästäisiin keskustelemaan, millainen talousjärjestelmä ylipäätänsä olisi 
järkevä. Tämä tarkoittaisi tietysti yhteiskunnallista palkkaa kaikille ja oikeutta ihmisille päättää itse, mitä tekevät elämällään.

Ja samalla tyäaikaa olisi lyhennettävä...

Ehdottomasti, siis jos oikeasti aiotaan pelastaa tämä planeetta ekokatastrofilta. On tärkeää muistaa, että uusliberalismi on aina talouden painottamista politiikan kustannuksella. Kapitalismi on saatava näyttämään ainoalta toimivalta järjestelmältä. Esimerkiksi prekaari työ ei tietenkään ole tehokkaampaa, kuten väitetään, vaan hyvin tehotonta. Kuitenkin se epäpolitisoi työn äärettömän tehokkaasti ja saa ihmiset työskentelemään ties missä ja ties miten sen sijaan, että he tekisivät jotain merkityksellistä. Se on naurettavan tuhlaavaa sosiaalisesti ja taloudellisesti. On kuitenkin pidettävä kaikin keinoin yllä ajatusta, että ainoastaan tämä vaihtoehto on olemassa, muutenhan ihmiset lähtisivät kaduille. Lopputulemana on täysin absurdi tilanne, jossa koko systeemi on hajoamaisillaan, mutta kapitalismi on silti ainoa järjestelmä, joka voi olla olemassa.

Asetelma muistuttaa Irakin sotaa, jonka lopputuloksena oli massiivinen tappio. Miksi sota hävittiin? Koska sodan tarkoitus oli lopulta estää sodan vastaisen liike kotimaassa. Tämä oli Yhdysvaltain johdolle tärkeämpää kuin itse sodan voittaminen. He määrittelivät laskentakaavan, joka arvioi, kuinka monta yhdysvaltalaisen sotilaan ruumista kestettäisiin tietyllä aikavälillä, jotta protestoijien määrä pysyisi sopivan alhaisena. Luulisi, että he olisivat laskeneet asian jo Vietnamin aikana!

Järkyttävä määrä naisia ja lapsia siis tapettiin, mutta ainoa asia, mistä huolehdittiin, olivat riittävän alhaiset sotilastappiot, jotta protesteja ei synny. Abbie Hoffmanin haamu siis voitti Yhdysvaltain armeijan! Tavallaan Yhdisvaltain johto pyörittää talousjärjestelmää samalla tavalla: kaikki mahdolliset vaihtoehdot on torjuttava kaikin keinoin, luhistuvalla järjestelmällä ei ole niin väliä.
VELKA, MARX JA

HISTORIAN VALLANKUMOUKSET

Olen lueskellut useita kritiikkejä Debt-kirjastasi. Useimmiten arviot ovat ylistäviä. Minusta näyttäisi siltä, että kirjan historiallinen analyysi velkarahajärjestelmien ja jalometallirahattomien sosiaalisten luottojärjestelmien vaibtelusta on hyväksytty subteellisen kattavasti. Kritiikki on kohdistunut läbinnä kirjan kabteen viimeiseen osaan, jotka käsittelevät velan ja finassijärjestelmän roolia kapitalismin aikakaudella.

Odotin huomattavasti kriittisempää keskustelua kirjani argumenteista. Syvällisiä kritiikkejä on tehty aika vähän. Tietenkin esimerkiksi historian eri osa-alueiden asiantuntijoilta kestää varmasti edelleen oma aikansa löytää kirja. Useimmiten olen saanut kuulla kritiikkiä siitä, että velkarahajärjestelmän ja väkivallan suhde pätee historiassa, mutta ei omana aikanamme. Giovanni Arrighihan ${ }^{3}$ on esittänyt Braudelin työhön perustuen, että kapitalistisen maailmanjärjestyksen hegemonia alkaa kilpailukykyisenä investointitaloutena mutta muuttuu ennen hegemonia-aseman menettämistä finanssivallaksi. Lisäisin tähän, että finanssivalta on aina sotilasvaltaa.

Ikään kuin liberaalin kapitalismin voittokulku olisi irrotettu historiallisesta kaavasta, jossa velkaraha on aina ollut sotien ja väkivallan synnyttämää. Ajatus on naiivi. Jos kuitenkin esität, että sama pätee maailmaan myös toisen maailmansodan jälkeen, saat kuulla olevasi salaliittoteoreetikko. Nykyinen Yhdysvaltojen finanssivalta perustuu väkivaltaan siinä missä sen historialliset edeltäjätkin.

\section{Ja sitten on marxistit ja palkkatyön historia.}

Eräät marxilaiset todella lukevat Marxia liian kirjaimellisesti. Luulin, että kirjani aloittaisi marxilaisten kanssa syvällisen väittelyn. Siksi- 
kin, että allekirjoitan suuren osan marxilaisesta taloushistoriallisesta analyysista. Perusargumenttihan on, että rahan perusta on palkkatyösuhteessa ja tätä ymmärtämättä ei voi ymmärtää, miten raha toimii kapitalistisessa yhteiskunnassa. Toisaalta sanotaan, että kapitalismi alkoi $1400-l u v u l l a$, vaikka palkkatyösuhde alkoi olla laajamittaista vasta teollisen vallankumouksen jälkeen.

Kapitalismissa on toki sille ominainen rahamuoto, pankkisysteemeineen, velkoineen ja osakkeineen, jota ei tapaa muissa historiallisissa yhteiskunnissa. Kaikki tämä oli kuitenkin olemassa jo ennen palkkatyötä. Samalla johtavat yritysmuodostelmat olivat koloniaalisia ja perustuivat pakko- ja orjatyöhön sekä velkavankeuteen. Mielestäni siis palkkatyön historiaa ei pitäisi määritellä liian tiukasti. Näin voisimme aloittaa kunnon debatin. Saan kuitenkin kuulla aina saman kritiikin: "Graeber ei ymmärrä, että rahamuoto on kapitalismissa erilainen palkkatyösuhteen vuoksi." Ikään kuin en olisi käynyt tätä ajatusta läpi! Koko kirja perustuu sille, miten rahamuoto muuttuu eri historian vaiheissa. Jotkut myös väittävät, että astun kirjassani ulos marxilaisesta työnarvoteoriasta, mikä on yhtä absurdia, koska en missään esitä tällaista argumenttia.

Nähdäkseni viime vuosina on herännyt laajempi kiinnostus historiallisen kapitalismin analyysiin. Eräänlainen 1960-ja 70-luvun sivilisaatiobistorian ja historiallisen sosiologian paluu. Kiinnostuksen kasvua selittänee osittain vuoden 2008 jälkeinen talouskriisi.

Aivan, koska yhtäkkiä on havaittu, että kapitalistinen järjestelmä saattaa hyvinkin tulla päätökseensä.

Jos ajattelet omaa työtäsi tai historiallisen analyysin mabdollisuuksia yleisemmin, niin mikä merkitys historian tutkimuksella on ajassamme, miten sitä tulisi tehdä ja millaisia poliittisia ulottuvuuksia tähän voisi liittyä?
Tieteen tekemisen innostavin puoli on usein se, että kiinnostavimmat näkökulmat pulpahtavat esiin silloin, kun niihin törmää sattumalta. Toki nämä voivat olla yksittäisiä teemoja tai opetuksia, kuten vaikkapa velka-armahdus, joka on ollut yhteiskuntien uudistumisen ja jälleenrakentamisen mahdollistaja. Nykyisin paasataan, että kaikki velat on maksettava takaisin, vaikka tiedetään, ettei tämä ole mahdollista. Tässä mielessä menneet sukupolvet ovat olleet meitä fiksumpia.

Historiaa ja antropologiaa yhdistää se, että parhaimmillaan ne vangitsevat kuvan siitä, mikä on ihmiselle mahdollista. Usein tutkija oppii sellaisia asioita,jotka ovat olleet ihmisille mahdollisia, vaikka niitä on pitänyt mahdottomina. Kuten vaikkapa sen, kuinka paljon erilaisia poliittisia ja taloudellisia muodostelmia itse asiassa voikaan olla olemassa.

Kun avarran näitä mahdollisuuksia, saan usein seuraavan vastauksen: "Totta kai eri vaihtoehtoja on ollut, mutta se oli aikaa jolloin ihmiset elivät kiinni turpeessa ja nyt meillä on tietokoneet, siksi historiallisilla vaihtoehdoilla ei ole merkitystä." Vastaan yleensä seuraavasti: "Olet siis sitä mieltä, että todistettavasti on ollut satoja erilaisia tapoja järjestää talous, mutta nyt kun meillä on tietokoneet, niitä on olemassa vain yksi. Ja minä kun luulin, että teknologian piti tarjota meille enemmän vaihtoehtoja!" Historia on siis tässäkin mielessä hyvin merkityksellistä.

Debtiä kirjoittaessani yritin päästä kiinni historialliseen rytmiin. Kun on pääsemässä kiinni johonkin historialliseen muutokseen, yksi tärkeimmistä asioista on ymmärtää, mikä mittakaava on merkityksellinen. Onko kyseessä mahdollisesti Kondratjevin sykli tai vuosisatainen aikaväli, kapitalismin tietty vaihe vai jokin muu. Debtiä valmistellessani ajattelin, että otetaan kerralla todella pitkä aikaväli, 5000 vuotta, ja vaihdellaan tämän jälkeen analyysinäkökulmaa edes takaisin velkarahakausien ja sosiaalisten luottojärjestelmien kesken. Nehän todella tapahtuvat vain noin tuhannen vuoden välein. Asetetaan tämän jälkeen lähtö- 
asetelmaksi, että meidän sukupolvemme on yhdessä näistä sykleistä, ja katsotaan mitä siitä seuraa. Asetelma todella muuttaa näkemyksemme käsiteltävästä aiheesta.

\section{Miten tämä kaikki on merkityksellistä kapitalismianalyysin kannalta?}

Kapitalismin syntyä on analysoitu vuosikausia, jotta voitaisiin ymmärtää, miten yhteiskunta muuttuu toisenlaiseksi ja kuinka kapitalismi voisi muuttua joksikin muuksi. Kun asetin Debtissä rytmin eri tavalla, yksi päätelmä oli, että ehkä katsomme kokonaan väärää historiallista muutosta. Ranskan vallankumouksesta asti on vallinnut päähänpinttymä siirtymästä feodalismista kapitalismiin, minkä jälkeen siirryttäisiin jälleen johonkin muuhun. ${ }^{4}$ Siirtymä on toiminut paradigmana kaikille historiallisille muutoksille. Mitä tahansa siis tuleekaan kapitalismin jälkeen, muutoksen täytyy noudattaa näitä ehtoja. Teoriat vallankumouksesta siis olettavat, että kaikki se mitä tapahtui Englannin vallankumouksen ja Ranskan vallankumouksen välissä, tulee tapahtumaan jälleen.

Merkittäviä historiallisia siirtymiä on kuitenkin ollut lukuisia. Rahajärjestelmän tarkastelun näkökulmasta, kun siis puhutaan siirtymästä jalometallirahasta virtuaaliseen luottojärjestelmään, siirtymä antiikista keskiaikaan on hyvin tärkeä. Paradigmana se näyttäisi kuvaavan jopa paremmin sitä, mitä on tapahtumassa juuri nyt: talouden kriisiytyminen, finanssijärjestelmän romahtaminen, ympäristökatastrofi ja massaliikkeet. Sikäli kun näin on, kyseessä on historiallisten yhteiskunnallisten liikkeiden aikakausi jota emme juuri tarkastele.

Rooman imperiumin purkautumisen aikaan orjuus lakkautettiin samaan aikaan lähes kaikkialla Euraasiassa. Yleisesti ajatellaan, että Rooman imperiumi hajosi erinäisiin katastrofeihin, ja sen jälkeen koitti pimeyden aikakausi. Kuitenkin 40 prosenttia Rooman valtakunnan väestä oli orjia: ei romahdus voinut heille kovin pahaa tarkoittaa. Ajankohtaan osuu yksi ihmiskunnan suurimmista massavapautumisista, (emmekä ole kiinnostuneita siitä, miten se tapahtui) mutta siitä puhutaan vain harvoin. Miksi emme siis ajattelisi vaihteeksi jotain muuta kuin siirtymää kapitalismiin?

Kirjassani Fragments of an Anarchist Anthropology väitin, että meillä on hyvin yksipuolinen näkemys vallankumouksesta ja muutoksen mahdollisuuksista. Tämä johtuu siitä, että olemme halukkaita katsomaan vain hyvin pientä osaa ihmiskunnan historiasta. Olemme luoneet käsitteelliset muurit, joiden mukaan kaikki, mikä tapahtui ennen teollista vallankumousta, on kuin toisesta universumista ja siten merkityksetöntä nykyhetkelle. Kuitenkin monet perustavat kulttuuriset ilmiöt, joita nykyisin pidämme itsestään selvinä, ovat menestyneiden yhteiskunnallisten liikkeiden saavutuksia. Nämä asiat eivät vain tapahtuneet, vaan ne olivat projekteja, joita ihmiset rakensivat. Samalla he kamppailivat siitä, millaisia ihmisten välisten suhteiden tulisi olla. On tapahtunut tuhansia erilaisia ja eri mittakaavan vallankumouksia. Aivan kuin vasemmisto haluaisi loputtomasti väitellä Kronstadtista, Pariisin kommuunista tai Espanjan sisällissodasta ja niin edelleen. Ei sillä, etteivätkö nämä esimerkit olisi käyttökelpoisia, mutta tämä kuulostaa siltä kuin olisi olemassa vain kuudesta kahdeksaan merkityksellistä tapahtumaa.

\section{DEMOKRATIALLA DEMOKRATIAA VASTAAN}

Nykyisessä poliittisessa kielenkäytössä sellaiset käsitteet kuin demokratia, vapaus tai vaikkapa ekologinen kestävyys ovat niin turmeltuneita, että ne ovat menettäneet merkityksensä. The Democracy Projectissa otat läbtökohdaksesi määritellä demokratia-käsitteen uusiksi. Kuinka tämä on ylipäätänsä mabdollista, ja kuinka se voidaan tehdä niin, että käsite olisi samalla radikaali ja emansipatorinen?

Kirjassa halusin yksinkertaisesti ymmärtää, kuinka oli mahdollista, että lähes kaikki ame- 
rikkalaiset rakastavat demokratian ajatusta, mutta samalla vihaavat poliitikkoja ja hallintoa. Demokratia ei siis voi tarkoittaa heille edustajien äänestämistä pyörittämään valtiota. Demokratian idea on ihmisille tuttu, mutta se on kaapattu muihin tarkoituksiin. Jos katsomme demokratia-käsitteen modernia historiaa, on aika selvää mitä tapahtui. 1700-luvulla demokraatti ja anarkisti tarkoittivat lähes samaa asiaa. Ne olivat haukkumanimiä. Kukaan ei halunnut kutsua itseään julkisesti demokraatiksi, aivan ääriradikaaleja lukuun ottamatta.

Amerikkalaisena totean usein mielelläni, että missään kohtaa itsenäisyysjulistusta tai perustuslakia ei puhuta demokratiasta. Niiden laatijat vihasivat demokratiaa ja näkivät perustuslaissa eksplisiittisesti mahdollisuuden rajoittaa sitä. Demokratian merkitys pakotettiin näiden kehysten sisään - ja valitettavasti me kaikki heittäydyimme siihen mukaan.

Herää kysymys, miksi heidän oli tehtävä näin? Miksi oli otettava omaksi demokratian käsite ja alettava yhtäkkiä kutsumaan itseään demokraateiksi ja puhumaan äänestämisestä? Näin tapahtui Amerikassa, Ranskassa, Kanadassa, Englannissa ja kaikkialla niin sanotussa läntisessä maailmassa. Muutos ei välttämättä ollut suuri, mutta se johtui vetovoimasta, jota kansa tunsi demokratiaa kohtaan. Yhdysvaltain perustajaisät ja heidän poliittiset jälkeläisensä olivat äärimmäisen järjestelmäuskovaisia. He uskoivat, että demokratia on hallinnointia, institutionaalisia järjestelyjä ja budjetteja, eikä kansalla kuulunut olla mitään tekemistä näiden kanssa. Itse asiassa heidän poliittiseen ymmärrykseensä ei kuulunut kansaa, koska he eivät luottaneet kansaan lainkaan, mikä tietenkin johtaa siihen, että kansa ei luota poliittiseen johtoon. Tämä kuitenkin antaa johdolle sen omasta mielestä oikeuden hyökätä yhteiskunnallisia liikkeitä vastaan.

Occupyn eräs kriittinen hetki oli, kun 9/11 jälkeen uudelleen militarisoitu poliisikoneisto iski voimalla mielenosoittajien kimppuun. Erityisesti valkoihoisten keskiluokkaisten protestoijien pieksämisen olisi odottanut nos- tattavan moraalisen paheksunnan liberaalien keskuudessa. Mitään ei kuitenkaan tapahtunut. Mielestäni tämä kertoo äärimmäisestä demokratian rajoittuneisuuden tilasta. Mikä tahansa toiminta, joka ei noudata omaksutun "laillisen demokratian" logiikkaa, tulkitaan nykyisin väkivallaksi, vaikka se olisi vain puistossa istumista. Olemme siis saapuneet pisteeseen, jossa ne, jotka ovat oppineet kutsumaan itseään demokraateiksi, pitävät varsinaista demokratiaa väkivaltana.

Yhtä kaikki, liike järisytti maailmaa. Edelleen occupy-malli pulpahtaa kerta toisensa jälkeen esiin ympäri maailman. Siitä ei pääse eroon, koska demokraattiset voimat käsittävät, että koko edustuksellinen järjestelmä on täysin korruptoitunut. Tämä tarkoittaa myös, että jos haluamme demokraattisen liikkeen, se on rakennettava kokonaan alusta. Ihmiset määrittelevät parasta aikaa millainen liike voisi olla. Minun ei tarvitse tätä työtä tehdä, minä vain raportoin.

The Democracy Projectissa kuvaat myös Occupy-liikkeen syntyhetkiä. Aluksi liike rakentui kokeneiden aktivistien spontaanin ideoinnin ja ybteydenottojen varaan. Varsinaisesti liike tuli vetovoimaiseksi siinä vaiheessa, kun tulevaisuushorisonttiin turbautuneet velkaantuneet opiskelijat tulivat mukaan. Tämän jälkeen liikkeeseen liittyi nopeasti sekä työväenluokkaa että keskiluokkaa. Kuinka paljon tässä kaikessa on kyse sukupolvikokemuksesta ja nuorten halusta määritellä politiikka omista lähtökohdistaan?

En tiedä, mikä tilanne on Suomessa, mutta yhdysvaltalaisille nuorille uusliberalismi on ainoa heidän tuntemansa järjestelmä, eikä heillä ole oikein mitään, mitä vastaan kapinoida. Heidän vanhempansa kasvoivat maailmaan, jossa oli tiettyjä laajoja historiallisia mahdollisuuksia. Nyt he kertovat jälkikasvulleen, että he eivät voi saada mitään näistä. Luulen, että tästä nousee syvä raivo.

Obama valittiin presidentiksi, koska nuorten alle 25-vuotiaiden äänimäärä kolminker- 
taistui. Kaikki se puhe muutoksesta ja toivosta - ja nuoret ostivat sen! Ja mitä he saivat? Kaverin, joka toimii vain silloin, kun asiat vaativat niiden säilyttämistä ennallaan, oli sitten kyse finanssisektorin pelastamisesta tai terveydenhuollosta jankkaamisesta. Ihmiset tunsivat tulleensa huijatuiksi.

Taannoinen gallup kertoo mielestäni paljon tämän hetken yhdysvaltalaisista nuorista. Siinä kysyttiin, mitä talousjärjestelmää kansalaiset kannattavat. Luonnollisesti kapitalismi voitti. 18-25-vuotiaat nuoret kuitenkin kannattivat voimakkaasti sosialismia, ja tulos olikin lähes tasan kapitalismin kanssa. ${ }^{5}$ Totta kai voi loputtomasti kysellä, mitä he tarkoittavat näillä käsitteillä, mutta kyseessä on kuitenkin maa, jossa sosialismia ei koskaan mainita positiivisessa valossa. Nuoret eivät siis välttämättä tiedä mitä sosialismi on, mutta ainakaan se ei ole kapitalismia. Tai vielä paremmin, mitä tahansa kapitalismi sitten onkaan, he haluavat ennemmin sen toisen mitä se sitten onkaan. He odottavat perustavia muutoksia. Ja tämä sakki uskoi Obamaan mutta sai uusliberaalin konservatiivin! Kuinka julmaa onkaan kiusata ihmisiä sillä kaikella puheella toivosta ja muutoksesta ja sitten sanoa, että kunhan vitsailin.

Tiedän, että olet joutunut tekemään kirjassasi rajauksia, mutta aion silti kritisoida demokratia-käsitettäsi rajalliseksi. Näbdäkseni demokratia määrittyy kirjassasi kulttuuriseksi käytännöksi. Tuet käsitystäsi historiallisella esimerkillä 1700-luvun alun Atlantin merirosvoista, jotka hallitsivat laivaansa konsensuksella ja hierarkiattomasti. Mutta tässä on vain osa tarinaa. Demokratiahan oli piraateille ehkä ennen kaikkea aluksen valtaamista yhteisomaisuudeksi ja merenkulussa vallinneen ankaran palkkatyösubteen lakkauttamista. ${ }^{6}$ Kirjastasi uupuu mielestäni näkemys ibmistyön haltuunotosta ja tuotannon demokratisoinnista.

Olet varmasti oikeassa. Minun oli kuitenkin lähdettävä liikkeelle demokratiasta ajatteluntaitona, koska tilanteemme on niin surkea.
Keskustelu yhteisvauraudesta (the commons) on myös mielestäni aivan keskeistä kaikessa siinä mitä nyt on käynnissä. Valitettavasti yhteisvaurautta ei ole enää juurikaan olemassa, vaikkakin samaan aikaan voidaan ajatella, että kaikki on yhteistä, työ, tieto ja niin edelleen. Yhteinen on myös demokraattisen liikkeen ytimessä, koska sen tarkoituksena on tehdä ihmisistä fiksumpia, ei tyhmempiä. Demokratiassa on kyse yhteisen älyn jakamisesta resurssina, eikä tälle resurssille taida löytyä vertaista.

Kuitenkaan se, että meillä on yhteisvarantoja ei vielä tarkoita että kykenisimme niitä hallitsemaan. Kun kyseessä on mikä tahansa ison mittakaavan resurssi, valtio astuu peliin ja asettaa resurssille joukon hierarkkisia määräyksiä. Esimerkiksi yksi ihminen voi aina omistaa auton, mutta verkostolle sen omistaminen on mahdotonta, koska juridisesti siihen tarvitaan yritys, jossa pitää olla toimitusjohtaja ja hallintohenkilöstö. Omistusoikeus ja hierarkkinen logiikka pakotetaan siis resurssiin väkivoimin. Jos et noudata heidän käskyään, he tulevat ja vievät autosi, ja jos et anna autoasi, he ampuvat sinut. Väkivalta ei lopulta ole niin kaukana näissä asioissa.

Kapitalistien raskain kalusto kohdistuu juuri yhteisvaurauteen. He ovat päättäneet, että emme voi hallita yhteisvarantoja. Jos pyörittäisimme menestyneesti yhteisvaurautta, se uhkaisi kaikkea sitä, mitä kapitalismi ja valtio opettavat meille ihmisen perimmäisestä luonnosta. Kapitalistit tietävät hyvin, että yhteisvauraus olisi heille lopun alku. Tämä näkyy esimerkiksi siinä, miten valtiota käytetään hyväksi julkista terveydenhuoltoa uudelleen järjestettäessä. Valtio sallii yksityistämisen ja sen, että yritykset pyörittävät hyvinvointia, mutta eivät voi mitenkään sallia universaalin yhteisvaurauden demokraattista järjestämistä voittoa tavoittelemattomalta perustalta. Yhteisöjen pohjalta organisoitavalle hyvinvoinnille ei itse asiassa anneta edes mitään mahdollisuuksia: jos yksityinen yritys ei toteuta palvelua tehokkaasti ja tuottavasti, valtio palauttaa sen itselleen hoidettavaksi. 
KOMMUNISMI, ANARKISMI JA

VALLANKUMOUS

Kuvailet kommunismia kaikista historiallisista ibmisybteisöistä löytyvänä vastavuoroisena käytäntönä, joka noudattaa periaatetta "kaikilta kykyjensä mukaan, kaikille tarpeiden mukaan". Miksi kommunismin ajatus tulisi rajata näin? Kommunismihan on myös määritelty "todelliseksi liikkeeksi, joka kumoaa vallitsevat asiain tilat". Marxille oli myös tärkeää puhua vapaiden ibmisten yhteenliittymästä, joka hallitsee yhteisesti tuotantovälineitään. The Democracy Projectissa toteat eksplisiittisesti, että kommunismilla ei ole mitään tekemistä ybteisomistuksen kanssa.

Tämä on hyvin kiinnostava keskustelu. Tarkoitan ehkä ennemminkin sitä, että kommunismia ei voi rajoittaa yhteisomistukseen. Toki yksityisomaisuuden lakkauttaminen voisi johtaa paljon kommunistisempiin suhteisiin, mutta ei välttämättä. On kuitenkin kuviteltavissa systeemi, jossa siirtymä omistusmuodosta toiseen tarkoittaisi vähemmän kommunismia. Seuraan tässä Marcel Maussia, joka kehotti olemaan katsomatta formaalia omistusmuotoa ja keskittymään siihen, kenellä on pääsy mihinkin. Lopulta se, mihin sinulla on pääsy, ja millä ehdoilla, ratkaisee. Omaisuuden pitäisi siis säädellä käyttöoikeutta. Yksityisomisteiseen resurssiin voi olla pääsy kaikilla tai vain yhdellä. Metsä voi olla maanomistaja Jussin, mutta kaikki voivat käyttää sitä. Tai sitten se voi olla Lordi Yrjön, ja vain hän voi sitä käyttää.

Idea liikkeestä, joka kumoaa kapitalismin on minusta hurmaava, mutta se perustuu messiaaniseen tai apokalyptiseen malliin, johon emme voi mielestäni enää luottaa. Luulimme tietävämme millainen tämä liike on, mutta olimme väärässä. Minulla ei ole riittävästi uskoa sanoa, että kommunismi olisi vääjäämättömästi liike, joka kumoaa nykyisyyden.
Lopuksi on pakko pubua kanssasi hetki anarkismista. Historiassa anarkistinen liike on muserrettu monin tavoin ja monien eri poliittisten vibollisten toimesta. Siis kaikessa lybykäisyydessään, millaisena näet anarkistisen politiikan mahdollisuudet 2000-luvulla?

Mahdollisuudet ovat huikeat. Joskus mietin kyllä, kannattaako sanaa anarkismi edes käyttää, koska sillä on hyvin sokeuttavia assosiaatioita. En ole varma, pitäisikö anarkismin sijaan puhua horisontaalisuudesta vai mistä, mutta lopulta nimellä ei ole väliä. Anarkistinen traditio on horisontteja ja etiikkaa, ohittamattomalla tavalla.

Vapaan yhteiskunnan rakentaminen tarkoittaa sellaisten käytäntöjen luomista, jotka eliminoivat pakkoja ja hierarkkista väkivaltaa tässä ja nyt. Samalla se tarkoittaa kapitalismin vastaista taistelua. Ei voi kuvitella pääsevänsä eroon ensin toisesta ja sitten toisesta. Voi jopa päästä eroon kapitalismista mutta päätyä pahempaan. Vapaata yhteiskuntaa ei voi jättää myöhemmin pohdittavaksi, vaan sitä on rakennettava välittömästi.

Etiikan osalta anarkismi tarkoittaa, että emme voi tehdä omien päämääriemme vastaisia ratkaisuja. Tämän vuoksi anarkismista on tullut tärkeää. Esimerkiksi nykyisillä anarkistisilla päätöksentekomekanismeilla on vähemmän tekemistä sadan vuoden takaisen anarkismin kanssa kuin vaikkapa feminististen tai eräiden hengellisten perinteiden kanssa. Jos vapaan yhteiskunnan horisontin luomisen käytäntöihin kytkeytyy jotakin siitä, miltä vapaa yhteiskunta voisi lopulta näyttää, ovat ihmiset valmiita siihen sitoutumaan.

Viime kädessä anarkistinen etiikka saa meidät pysymään rehellisinä: vapaata yhteiskuntaa ei voi luoda käyttämällä väkivaltaa, eikä demokratiaa olematta demokraattinen tai vapaita ihmisiä suosimalla totalitarismia. Saattaa kuulostaa yksinkertaiselta, mutta nämä ovat anarkistisen horisontin opetuksia. Tästä anarkismissa on kyse, kompromissittomuudesta näissä periaatteissa. 
Ja miten tämä kaikki liittyy vallankumouksen mabdollisuuteen?

Vallankumous on muutos ihmisten perustavassa poliittisessa ymmärryksessä. Se tekee mahdolliseksi prosessin, joka voi johtaa laajaan yhteiskunnalliseen muutokseen. Muutos tarkoittaa nimenomaan muutosta mahdollisuuksien horisontissa. Ihmiset, jotka ovat eläneet

1. Panoptikonista ja sen merkityksestä lontoolaisen proletariaatin pakottamisessa palkkatyöhön ks. Linebaugh, Peter 2006. The London Hanged. London: Verso, s. 371401.

2. Ks. "On the Phenomenom of Bullshit Jobs", http:// www.strikemag.org/bullshit-jobs/, katsottu 30.5.2014.

3. Arrighi, Giovanni 2010. The Long Twentieth Century. London: Verso.

4. Siirtymä-ajatus kiteytyi toisen maailmansodan jälkeiseen länsimaisten marxistien taloushistorialliseen kiistaan siitä, kuinka siirtymä feodalismista kapitalismiin tapahtui. Kiista tunnetaan nimellä siirtymä-keskustelu. Katso Hilton, John, et. al. 1986. Uuden maailman synty. läpi vallankumousten, puhuvat yhtäkkisestä mahdollisuuksien laajentumisesta. Vallankumouksen ei tarvitse olla väkivaltainen, vaikka toki usein näin on. Vallankumouksessa on kyse siitä, että asiat jotka näyttivät mahdottomilta tai kuvittelemattomilta ovatkin äkkiä yhteistä arkiymmärrystä.

Haastattelu ja suomennos Tero Toivanen

VIITTEET

Feodalismista kapitalismiin. Tampere: Vastapaino.

5. "Little Change in Public's Response to 'Capitalism', 'Socialism'." A Political Rhetoric Test 28.11.2011. http:// www.people-press.org/2011/12/28/little-change-inpublics-response-to-capitalism-socialism/?src=prcheadline, katsottu 20.5.2014.

6. Piraattien radikaalista historiasta katso Linebaugh, Peter \& Rediker, Marcus 2006. The Many-Headed Hydra. London: Verso; Rediker, Marcus 2011. The Villains of All Nations. London: Verso. 